\title{
Another modern nymph: The pin-up as Aby Warburg and Georges Didi-Huberman's nymph
}

Quote: CAMPOS, Daniela Queiroz. Another modern nymph: The pin-up as Aby Wargurg and Georges Didi-Huberman's Nymph. Porto Arte: Revista de Artes Visuais. Porto Alegre: PPGAV-UFRGS, v. 22, n. 36, p.1-8, jan.-jun. 2017. e-ISSN 2179-8001. DOI: http://dx.doi.org/10.22456/2179-8001.80111

Translated by Ana Carolina Azevedo and Bruno Declerque

Abstract: This article discusses a possible incarnation of Aby Warburg and Georges Didi-Huberman's nymph. The work addresses the temporalities of the image of Alceu's column Girls (Garotas) in the magazine $O$ Cruzeiro. A humor and behavioral column that was edited from 1938 to 1964 in one of the most popular Brazilian magazines of the $20^{\text {th }}$ century. The column was marked by its illustrations signed by Alceu Penna. The perceptions and chronicles of the image perpass questions related to its time of production, to its reproducibility, to the graphic industry. They were images surrounded by advertisements, behavior, morals and fashions in vogue in its historical production time. However, according to Georges Didi-Huberman, the image belongs to time. Multiple, impure, heterogenic, dialectic, anachronic times also permeate the images in study. Alceu's Girls, the pin-ups, were analyzed as nymphs. Pin-ups were one of the landmarks of 20th century press and they divided the pages of periodicals with war. The Girls, like the modern nymph, who associate beauty with trauma.

Keywords: Image. Nymph. Memory. Anachronism. Pin-up.

\section{A NYMPH - BETWEEN THE BEAUTIFUL AND THE TRAUMATIC}

The nymph. A minor deity with no instituted power, but of radiant and true power of fascination (DIDI-HUBERMAN, 2002, p.7). The Nymph and her disparate apparitions. Singular and plural, disquieting. Between falling and draping, let us draw the Nymph into what perhaps shapes her image: trauma. The beautiful female body. One of the great images of Westernness in the long run. Our great museums are full of them. The beautiful female apparitions. Sweet and erotic. Perhaps as present as her - the image of the feminine beauty, there is only another image - the image of death. The image made from image, image, the image, imago (DEBRAY, 1993).

Between the entrances and exits of museums, between the opening and closing of books, between the pages of magazines, two bodies. Two great bodies. The erotic body and the dead body. What are the connections, the possible dialogues, the relations between these two bodies? The beauty, the pleasure, the desire. The death, the pain, putrefaction. Is there, perhaps, something that could link these two great bodies? The exhibition The Angel of the Odd, held in 2013 in the Musée D'Orsay, had in one of its walls the following words, in an explanatory text " $\mathrm{La}$ beauté est selon lui l'instrument grâce auquel la Nature poursuit son objectif de maintien de l'espèce sacrifiant à as volonté le bien être des individus, dupés par le plasir charnel et vaincus par la mort" ${ }^{\prime \prime}$. The femme fatale as allegory of the concept of Nature, as a cruel, destructive and perverse force when one plunges into its secrets. A typically sadistic nature, the theme that subverts the myth of the good mother nature.

The beauty, the desire, the erotic, the pleasure and the death. The beautiful female image seems to be interpenetrated by guilt, pain, and trauma. It was the woman and her beauty, the generator, the culprit for the widespread of evil in the world. Our first mother doesn't cease to be one of these women. Eve, the beautiful Eve, who seduced Adam and expelled us from the Edenic paradise. The beautiful and dancing Salome, who charmed Herodias and showed off the decapitated head of St. John the Baptist. The Venus, who offered Helen to Paris and unleashed the Great Trojan War. Where would this desirous body, this femme fatale, the carnal pleasure be? Has woman spread evil throughout the world? And, why does she never seem to stop crying over her own trauma?

A question was asked to the then young and recent-doctor Aby Warburg: After all, who were the Nymphs, and where did they come from? (AGAMBEN, 2010, p.19). About a century later, Georges Didi-Huberman posed another question: Where do all the Nymphs from this subtle pantheon go? (DIDI-HUBERMAN, 2002, p.11). So who are the Nymphs? Objects of love passion per excellence (BRANDÃO, 2010, p.172). Memory, desire and time (DIDI-HUBERMAN, 2002, p.7). A rough sweetness (AGAMBEN, 2010, p.40). The

1. Beauty is, according to it, the instrument by which Nature pursues its objective of maintaining the species, sacrificing at will the well-being of individuals, duped by carnal pleasure and vanquished by death. (Translated by Bruno Declerque) Text linked to an explanatory panel at The Angel of the Odd Exhibition at the Musée D'Orsay in 2013. Paris. 
absence of the soul and the presence of death. As occupation, the search for love. As mission, the seduction of man. A being that belongs to the Realm of Venus. But... The Nymph dies. The celebrated Nymphs, the heroines of the Warburguinian Narcheleben (DIDI-HUBERMAN, 2013, p.219).

We may think that two of the great Warburg's Nymphs, Simonetta Vespucci and Giovanna Tornabuoni, were dead women. They were dead even at the time those images that immortalized them were made. Panel number 46 from the Atlas Mnemosyne (WARBURG, 2010, p.85) seems to pursue the image of Giovanna Tornabuoni. There, she is presented to us through the brush strokes from Domenico Ghirlandaio ${ }^{2}$ and Botticelli ${ }^{3}$. Coined in money ${ }^{4}$, painted in frescoes, on canvas or on paper, we can see the young wife of Lorenzo Tornabuoni, who died giving birth at the age of 20. The Nymph Simonetta Vespucci had also been the object of thought of Aby Warburg, still in his doctoral thesis, he analyzed it in Botticelli's Flora ${ }^{5}$ (WARBURG, 2013). Simonetta has given her likeness to Cleopatra from Piero di Cosimo6 6 and two portraits of a young woman ${ }^{7}$ from Botticelli. The wife of Marco Vespucci and lover of Giuliano de 'Medici, also died at 20 years of age.

The warburguinian Nymph, as emphasized by Agamben, stood out for its originalities and repetitions, whose origin and becoming would be time (AGAMBEN, 2010). The time... The Antiquity, the Renaissance and the contemporaneity side by side. Nymphs of this infinite montage of multiple temporalities. The Nymph was not only restricted to panel number 46, in Atlas Mnemosyne. The beautiful apparition moved like spirits by many of the black panels and works of Warburg, as it is a characteristic of his. In one of the last panels of his Atlas - on panel number 77 - Warburg proposed a modern Nymph in advertising images of the $20^{\text {th }}$ century.

2. Domenico Ghirlandaio, Visitation.. Fresco, 1485-1490. Chapel of the choir, Santa Maria Novella, Florence and Portrait of Giovana Tornabuoni, Tempera on panel, 1488, Thyssen-Bornemisza Collection, Madrid.

3. Sandro Botticelli, Venus and the Three Graces Presenting Gifts to a Young Woman, Fresco, 1485-1490, Louvre Museum, Paris.

4. Niccolò Fiorentino, Giovanna Tornabuoni Medal, 1486.

5. Sandro Botticelli, The Birth of Venus, Tempera on canvas. 1483 - 1485. Uffizi Gallery, Florence.

6. Piero di Cosimo, Simonetta Vespucci, Tempera on canvas 1480, Château de Chantilly.

7. Sandro Botticelli, Portrait of a young woman, Tempera on canvas, $1480-1485$, Städelsches Kunstinstitut, Frankfurt and Portrait of a young woman, Tempera on canvas, 1476-1480, Gemäldegalerie, Berlin.

\section{A PIN-UP - BETWEEN REMEMBERING AND FORGETTING}

Let us then look for the Nymph in perhaps the most casual, in the ordinary. Let us locate the Nymph in her most celebrated and vulgar presentation Nymph the beautiful female body. In a popular place of wide circulation - on magazine pages. A Nymph, a woman, a doll. A pin-up. Characteristic image of the $20^{\text {th }}$ century. A beautiful young woman, a sinuous and erotic body. A press image. An image that marked, above all, the Great War. Not the Great Mythical War, but the Great World Wars of the $20^{\text {th }}$ century.

The pin-up illustration genre stands out, specially, during the World War II. The magazines were taken to the battlefield by soldiers. In its pages, the beautiful pin-ups. If Helen was the great muse of the Trojan War, the pin-ups were the muses of World War II. "La Seconde Guerre Mondiale represente dans l'histoire de la pin-up um moment de cristallisation. Cette période peut être qualifiée d'âge d'or de la pin-up puisque celle-ci envahit rapidement tous les lieux possibles soud différents formats et supports"8. During the War, they did not cease their presentations. Sometimes dressed in navy uniforms, sometimes wearing army uniforms, sometimes wrapped in starry flags. At first, it was a landmark of the American press, then it gained several nationalities, different adaptations, disparate presentations. They were everywhere. They were displayed in cigarette packs and in the human skin in the form of tattoos. And that was how that they reached their extreme presentation: the warplanes.

The beautiful apparitions. The beautiful and seductive dolls also went to the War. They were there. Apparently in the place of forgetting. In the moment of individual pleasure that soothed the desiring body of the soldier on the battlefield. On the printed pages, they participated in the War in an unimaginable way. Unimaginable and simple at the same time. They were there, illustrated and photographed. The apogee between the erotic body of the pin-up and the debris of war was Hiroshima. "Cette association femmes sexy et objet de guerre trouve son apogée avec la présence de pin-up sur les bombes larguées par les avions. Rita Hayworth (1918-1987) aurait été dessinée sur les bombe atomique lânchée sur Hiroshima"s. Aircrafts intended to

8. The World War II represents in the history of the pin-up the moment of crystallization. This period can be called the golden age of the pin-up, as it quickly invades every possible place in its different formats and supports. (Translated by Bruno Declerque). FAVRE, Camille., 2007. p.39.

9. This association between sexy women and the object of war finds its apogee 
send men to kill other men. Aircrafts destined to send bombs to annihilate trenches, battlefields, cities... There, the image of a doll. The image of a beautiful female body. The ideal body next to the mutilated body of the soldier. The erotic body of paper besides the dead body of flesh, bone and blood.

They were the place of forgetting. They were the image of forgetting. The forgetting, to breathe in hard times. Their role was to give relief to the body. Their role was to take the minds of the ones who watched them off things, whether on the battlefield or at home, surrounded by news with the hard images from that hard War. The place of the frivolous, the place of the futile, but the place so necessary.

The magazine pages carried images of battlefields, of bombardments, of cities annihilated, of hundreds or thousands of dead men, of mass graves. These were the great images of the press during the War. In Brazil, the images of the confrontations that occurred in Europe, in that World War II, were news. These were many... They were there in the movies, on the radio, on the pages of newspapers and magazines. Among this many texts and images about the War, many other pages were practically oblivious to everything that happened. They were the pages dedicated to clothes and shoes, to cake recipes, to labels, to diets, to makeup. They were pages dedicated to a group of beautiful girls, which talked about the light routine of those young woman. The pin-ups were the ones who weekly illustrated, in the pages of the magazine $O$ Cruzeiro, the 'modern' good life of the wealthy Brazilians.

\section{A GIRL - BETWEEN WAR AND PEACE}

The Girls (Garotas) were the characters and the title of a wellknown column of pin-ups from the Brazilian magazine of wide circulation: O Cruzeiro. The so-called Alceu's Girls headlined the pages in tabloid format from the magazine from 1938 to 1964; they were featured weekly for uninterrupted 27 years in the same magazine. It consisted of an illustrated column of young girls, that talked about their daily lives in that mid-twentieth-century Rio de Janeiro. The texts were linked to the drawings from Alceu Penna, texts signed by different writers throughout the years of edition. The column Girls was considered the "expression of modern life

in the presence of the pin-up on the bombs dropped by the planes. Rita Hayworth (1918-1987) was drawn as a pin-up on the atomic bomb lashed on Hiroshima. (Translated by Bruno Declerque). FAVRE, Camille., 2007. p.49. in Brazil", it weekly presented groups of beautiful young women dressed according to the latest fashion trends, talking about the most diverse subjects.

During World War II, we have two Girls columns that addressed that Great Mythical War, the Trojan War. The pin-up shaped the three goddesses and placed Paris before his great choice.

At Peleus's wedding to the goddess Thetis, all gods were invited except Eris, the goddess of discord. Eris's non-invitation to the wedding generated the discord. The goddess Eris wrote "The most beautiful" in a golden apple. The three Goddesses: Venus, Hera and Athena disputed for the apple, for the title. One choice, one title: the most beautiful. Which of the three would be the most beautiful. Zeus did not want to be the judge to not put himself in a disharmonized situation with the two goddesses who did not win the title. As a judge, they chose Paris, the Prince of Troy. In the dispute, each of the three offers different gifts to be chosen as the most beautiful among all the goddesses. Athena offers Paris power in battle and wisdom. Hera offers wealth and power. Aphrodite offers him, in this kind of mythical blackmail, the love of the most beautiful woman in the world.

Once again, the beautiful apparition. The beautiful female body. The great trauma. Paris makes his great choice. Between the power in battle and wisdom, wealth and power and the love of the most beautiful woman in the world. The desire and the beautiful were the choice of the Trojan Prince. The carnal love, the female beauty. Paris gave Aphrodite the title. In return, he won the love of the most beautiful woman in the world: Helen.

The beautiful and stunning Helen, daughter of Leda and Zeus, and married to the king of Sparta, Menelaus. Paris wins Helen and takes her to Troy, fleeing from her husband. In response: a war - the Trojan War. The Great Mythical War, the narrated war, the sung war, the written war, the painted war. The war that did not cease its apparitions. And there, in the middle of the $20^{\text {th }}$ century, in the middle of World War II, it became contemporary.

Another war, another trauma, another apple. A golden apple and a choice: the most beautiful. The same story narrated and drawn by Alceu Penna. The image of a beauty contest so common in those mid-twentieth-century. A Miss Universe contest. Each of the three goddesses with a sash that did not 
have the name of their countries, but their own name, the name of a goddess. Three beautiful young women in swimsuits wanting to be chosen by the judge Paris. A man with his back to us. A man with his back to the picture, his back to us. His eyes belong to the most beautiful, the most traumatic. The choice that would cause the most reminiscent of all wars.

The three Greek goddesses presented as pageant girls. The most beautiful goddesses of the Pantheon presented as the most beautiful women of the $20^{\text {th }}$ century. The column that dealt with contemporary themes with manners of Antiquity. It talked about the women of its time of production, there, Antiquity and Modernity were merged together. Famous monuments to beauty, restored and remembered in women who allude to a Classical Antiquity. The Antiquity and the $20^{\text {th }}$ century seem to be mixed with so many historical times in Penna's column. The images are situated at different, multiple and confusing times.

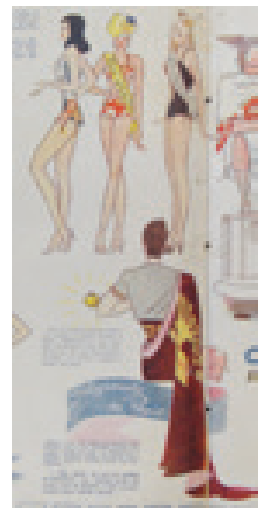

Figure 1. Detail of Girls in mythology. 0 Cruzeiro Magazine. March 28 ${ }^{\text {th }}, 1942$, year XIII, $\mathrm{n}^{\circ} 22, \mathrm{p} .20$ and 21. Archive: Mario de Andrade Library

The same judgment of Paris was addressed by Aby Warburg on panel number 55 of his Atlas Mnemosyne (WARBURG, 2010, p.101). We see, among the images approached by Warburg on the panel, paintings, engravings, drawings, frescoes. The painting from Anton Raphael Mengs presents us the three beautiful naked goddesses. The prudish Venus, Minerva and Juno and one, also naked, Paris wearing a red and long cape. In his hand, the same apple of discord and a simple and complex choice, the most beautiful. The choice that will lead to war.

Three beautiful female bodies. Venus, in the center, frontally faces the spectator of the image and Paris, the unfortunate judge. She stares at him confident of her beauty and the choice of the young man. Alceu Penna's Venus has the details of her body censored by one, so-called at the time, two-piece bikini. Anton Raphael Mengs' Venus presents the gesture of a heavenly and prudish Venus (CLARK, 1953), with her left hand hiding her pubic region. However, both have the same gestures. They support the right hand at the waist, forming with the elbow a triangle at the waist area. A gesture that convinces me of their confidence and, perhaps, audacity in face of that game of gods with humans. The same confidence, the same gesture, the same war, or are they two different wars?

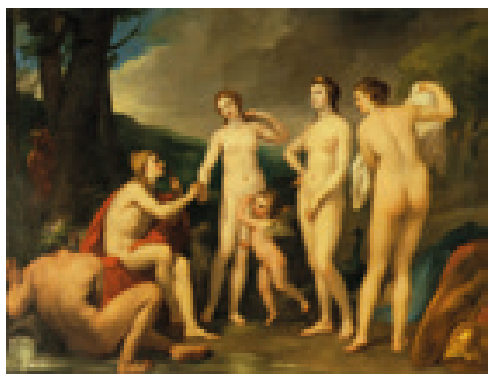

Figure 2. The Judgment of Paris. Anton Raphael Mengs. Oil on canvas, 1757. Hermitage Museum, Saint Petersburg

Unlike Anton Raphael Mengs' painting, Alceu Penna's column didn't have any background. An image with no background, no land and no sky. An image almost with no context. But, perhaps, the context of that image should not be sought in a supposedly other image illustrated behind curvy dolls, but in the very element that the background marked: the press paper itself. The same paper that had served as support for the entire magazine. The context was the paper, that world of paper.

That tiny world, practically dedicated to the forgetting, those two pages dedicated to the daily life, the frivolous life of a wealthy young woman. "[...] We can never say: there is nothing to see, there is nothing else to see. In order to know how to distrust what we see, we must know more, see, despite everything "(DIDI-HUBERMAN, 2013b, 127). A column about the great mythical war in 1942, in the middle of World War II. And the column Girls never dealt with the war, something so mundane, roughly unattractive to the dappled and nimble eyes of a young pin-up. To understand the power of the time... The power of the image in time. A simple and important lesson.

The image of forgetting war. Perhaps this image of forgetting also tells us something very pertinent about the war. Sometimes it takes only five minutes. Sometimes it is necessary to paint with a crayon a line, almost imaginary, behind the legs, for 
others and for yourself. A nylon sock, something so simple, so ordinary, so superfluous, so superficial, nylon, material that was expensive and difficult to access during the war. And its absence felt in the body. Or rather, its absence felt on skin. In the superficial skin. The skin. For Didi-Huberman, the apparition surface endowed with life. For Valéry, the deepest.

\section{A BODY - BETWEEN CONSTRUCTION AND DECONSTRUCTION}

That was a time of construction of bodies. The time they constructed, from paper and plastic, perfect bodies, outlined bodies, designed, built. The $20^{\text {th }}$ century was consecrated by its pin-ups and its Barbies. The dolls stopped being just an object of childish games. The dolls stopped being just an object of children's desire. The dolls got bodies of adult women, bodies desirable by men, by women and also, and why not, by children. The plastic doll was created only in 1959. While our paper dolls crossed the entire $20^{\text {th }}$ century, its Wars destroyed bodies. The construction of perfect bodies in paper gained other supports, as the already mentioned warplanes. But an interesting question in relation to this period would be the construction and annihilation of bodies.

The $20^{\text {th }}$ century annihilated bodies. It annihilated, and more than that, it recorded this annihilation of these bodies. The photographic camera, invented in the $19^{\text {th }}$ century, recorded the frightening dismantling of $20^{\text {th }}$ century bodies. World War I left a swarm of mutilated, amputees. That was still a trench War. A war of body remains.

The years contemplated by our column on Troy were years marked by a massive destruction of bodies. During this time, the gas chambers were installed for mass asphyxiation at Auschwitz. A swarm of dead bodies was the main matter formed by the concentration camps. It is confusing to think of this place of barbarism as a place of culture, a place changed by the sometimes incomprehensible human task of remembering and transforming that memory into a kind of "visitable" place. This "Auschwitz as Lager, a place of barbarism, was undoubtedly transformed into a place of culture, Auschwitz, the 'state museum', and it is better this way. The real question is to know of what kind of culture this place of barbarism has become the exemplary public space " (DIDI-HUBERMAN, 2013b, p.105).

The disappearance of an infinity of bodies, the scrapping of bodies in a time that does not stop to construct idealized bodies. Nazism, in a way, also constituted itself in a constructing apparatus of ideal bodies and minds. Pin-ups beautiful bodies spanned the entire $20^{\text {th }}$ century. Some may point out that those doll images, which were spread through the world by the American soldiers, were soon on the other side of the same War. But the point is that, perhaps, we should think not of a two-sided War, but of the War with its battles and its bombardments. A war as an apparatus of destroying human bodies.

The construction of perfect bodies and the destruction of human bodies. Something that marked the $20^{\text {th }}$ century. Something so present and something so past. The construction and deconstruction of bodies and their terrifying anachronism, their terrifying survival. Something so simple and so inappropriate. Something so possible and so impossible. Something so close, a terrible temporal proximity of less than 100 years. And something so far.

The Greeks were very competent in destroying and constructing bodies. They also annihilated human body, flesh, and blood and constructed beautiful stone bodies. Perfection in carved form, perfect human form, but impenetrable like marble. Hard, rigid, immortal body. But a body that, as an image per excellence, marked death. The body as the traumatic element itself. The Nymph and her fall. The woman who cries and seduces us. This almost sweet rough state of the feminine. The image of forgetting and the image of remembering. The woman who even generates the trauma, the guilt. Woman who produces milk and blood (DIDI-HUBERMAN, 2013c, p.32). The beautiful and young Aby Warburg's dead Nymphs. The erotic body and the dead body. The danger of the beautiful and the traumatic.

If the $20^{\text {th }}$ century constructed and deconstructed bodies. Many other centuries have also done so. The $21^{\text {st }}$ century is still replete with this construction and this deconstruction of the body. Each era constructs and deconstructs bodies in singular and plural forms. But today, perhaps, the scar of the $20^{\text {th }}$ century is still a little open and somewhat remedied for us to be able to dwell on it.

That was the century of the two Great World Wars. That was the century of Nazism and its holocaust, between battlefields and concentration camps, beauty contests and pin-up magazines. At the beginning of the $20^{\text {th }}$ century, the beauty contests 
were created (FLORES, 2000). In the $20^{\text {th }}$ century, the pin-ups appeared and became popular in both fashion magazines and the so-called "men's magazines". Nazism itself was a great political apparatus for the deconstruction of "filthy" bodies and the construction of beautiful and Aryan bodies.

At that time, the pin-ups spread throughout the world with speed and with the periodic press technique. The soldiers, on the battlefields, were almost fed by these images. According to editorials from the American magazine Esquire, 9 million copies of the magazine were sent as free copies to troops in combat. There, they should control sexual drives, fight against homosexuality, serve as support for masturbation. During the conflict, that type of print has multiplied. After it, these erotic images, even though they were modified, continued to grow and spread in magazines of great circulation. Let us recall here that the first number of the American Playboy dates back from 1953, and the French Lui begins its circulation in 1963.

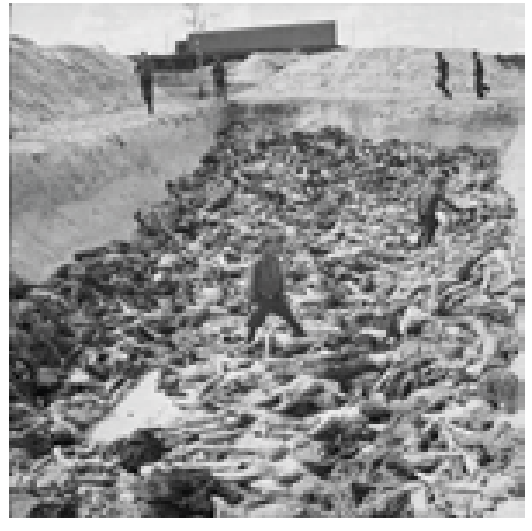

Figure 3. Mass grave in the extermination camp of Boelcke-kaserne. In 5 Army Film Photographic Unit \&, Oakes, H (Sgt), 1945No 5 Army Film \& Photographic Unit, Oakes, H (Sgt), 1945.

The paper dolls. The beautiful bodies constructed by the press that did not cease producing dolls. At that same time, lean and humiliated human bodies were destroyed by a great construction apparatus of ideal bodies. Photographs of that pile of dead human bodies, human beings almost torn from their carnality. Dead bodies that would not receive their own tombs, that remained with the pseudo-homage of monuments without bodies.

The mass grave, a pile of broken and dead bodies, can be the Dionysian backdrop of beautiful and apollonian images of pin-ups. Some may consider that these images are on opposite sides of a War. That the allies, the great constructor of paper bodies were saving mankind from the woes of Nazism, but we know that this story is not so simple. We know that these images are not so definitive. War deconstructed bodies. Amputated limbs. Destroyed cities. Bombed, killed, destroyed, annihilated. World War II demolished millions, countless bodies. The numerous images of bombings and conflicts lived side by side with the pages designed for beautiful pin-ups. The dead body and the erotic body divided the pages of the same magazines.

\section{A DOLL - BETWEEN ASSEMBLING AND DISASSEMBLING}

The trauma and the image. The erotic body and the dead body. The constructed body and the deconstructed body. The paper doll and the flesh-and-blood body. The dolls were a place of construction of an ideal female body. But they were also used as an apparatus that marked this deconstruction.

Alceu Penna constructed the bodies of his dolls that were published in the $O$ Cruzeiro magazine weekly in the same way that many other designers and photographers have done for countless periodical magazines around the world. They constructed idealized, erotic, desirable female bodies. Other men, however, constructed other types of dolls, other types of bodies. Maybe they deconstructed this human anatomy.

Inside a suitcase, in the sculpture Zuge in leben Zuge in den tod we have a shattered doll. Its torso lost one leg and both arms. The shapes of the bronze doll remind us of the plastic dolls, idealized constructions of beautiful and perfect babies constructed and reproduced by the toy industries of the whole Westernized world. Maybe the first constructed body that we still have contact in childhood. In the sculpture, the chubby body of the doll had been scrapped, perhaps like the body of the child to whom it belonged. The sculpture Zuge in leben Zuge in den tod was made to appear on the background of the great train station in Berlin. From that station, children left for life and children left for death. German Jewish children went daily to two destinations: to be adopted by other Jewish families in England or to go to concentration or extermination camps in Poland and in Germany itself. The scrapped doll is in an open suitcase, the children's suitcase that went to the scrapping of bodies. The bronze sculpture was made by a German plastic artist of today. The sculpture was made by 
one of those children who left from that same station years ago. He did not survive the camp because he had never been a prisoner of one. But honestly, I don't believe that the broken doll wasn't also about her.

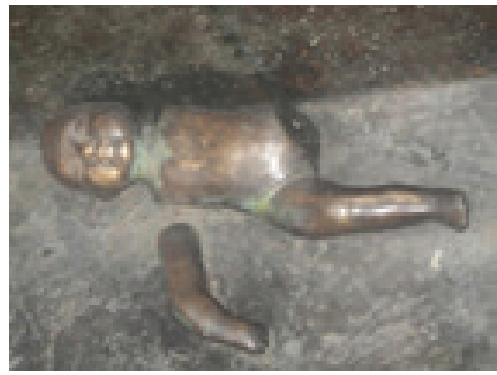

Figure 4. Detail of the sculpture. Frank Meisler. Zuge in leben Zuge in den tod. Bahnhof Friedrichstraße, Berlim.

A world of dolls. Designed, traced and colored dolls. Beautiful photographed dolls. The idealized construction. The thought, reflected, calculated destruction. A constructed doll. A deconstructed doll. One does not construct one thing without deconstructing another. To construct one body, it is necessary to deconstruct another.

\section{BUT AFTER ALL...}

Who are the Nymphs and where did they come from? With eyes closed and according to its true essence.... Aby Warburg's answer still fits the question. More than a century after it was formulated and answered, it seems to fit into this unfitting of images. Nymphs are elemental spirits, they are pagan goddesses in exile. And where did the nymphs of the pantheon go? Georges Didi-Huberman elaborated a beautiful question and answered it magnificently. The almost sacred nymphs of the pantheon, the erotic and disturbing, the Nymphs, went to many places in inconstant times.

The pin-ups are a possible incarnation of the Nymph, as the Goddesses of the Pantheon are a possible incarnation of Alceu's Girls. Maybe they are all about the same thing. Memory, desire and time. Aby Warburg essayed, in his Atlas Mnemosyne, a Modern Nymph in images from the periodic press of the $20^{\text {th }}$ century. Georges Didi-Huberman wrote magnificently about another version of this Modern Nymph in 2002. Here, modestly, I propose another one: No less beautiful, no less traumatic. Just another possible incarnation of this impersonal heroine.
Each of these images has an indescribable degree of beauty blended into trauma, from entangled passion to pain, from obsessive desire of death. The characters created by Alceu Penna, to be featured in that column from the 0 Cruzeiro magazine, were this femininity in movement, they were that true plastic figure on which Warburg wrote so much.

\section{REFERENCES}

AGAMBEM, Giorgio. Ninfas. Tradução Antonio Gimeno Cuspinera. Valência: Pré-textos, 2010.

DEBRAY, Régis. Vida e morte da imagem. Petrópolis, Vozes, 1993.

DIDI-HUBERMAN, Georges. A imagem sobrevivente. História da arte e tempo dos fantasmas segundo Aby Warburg. Translated by Vera Ribeiro. Rio de Janeiro: Contraponto, 2013a.

. Atlas: ¿Cómo llevar el mundo a cuestas? Presentation text written by Georges Didi-Huberman at the floolder of the eponymous exhibition held at the Reina Sofia Museum, Madrid, March 2011. . Blanc soucis. Paris: Minuit, 2013c.

_.Cascas. In: Revista Serrote.Volume 13. São Paulo: Instituto Moreira Salles, 2013b. . Imágenes pense a todo: memoria visual del Holocausto. Barcelona: Ediciones Paidós Ibérica, 2004. . La pintura encarnada. Valencia: Universidad Politécnica de Valencia, 2007.

. La ressemblance par contact. Archéologie, anachronisme et modernité de l'empreinte. Paris : Les Éditions Minuit, 2008. . Las condition des images par Didi-Huberman. IN: AUGÉ, Marc; DIDI-HUBERMAN, Georges; ECO, Umberto. L'experience des images. Paris: L'eu editions, 2011. . Ninfa Moderna. Essai sur le drape tombe. Paris: Gallimard, 2002. . O que vemos, o que nos olha. São Paulo: Editora 34, 2010. . Ouvrir Venus. Nudité, rêve, cruauté. Paris: Éditions Gallimard, 1999.

Sobrevivência dos vaga-lumes. Belo Horizonte: Editora UFMG, 2011. P.119. . Venus rajada. Buenos Aires: Editorial Losada, 2005.

SISSA, Giulia. Sexe et sensualité. La culture érotique des anciens. Paris: Odile Jacob, 2003.

WARBURG, Aby. Atlas Mnemosyne. Madrid: Impresos Cofás S.A. 2010. 
. A renovação da Antiguidade pagã. Contribuições científicoculturais para a história do Renascimento europeu. Rio de Janeiro: Editora Contraponto, 2013.

_. El Renacimiento del paganismo. Aportaciones a la historia cultural del Renacimiento europeo. Madrid: Alianza Editorial, 2005.

. Imagens da região dos índios pueblos na América do Norte. IN: Revista Concinnitas: artes, cultura e pensamento. Year 6, Volume 1, Number 8. Rio de Janeiro: UERJ, July 2005.

YATES, Frances Amélia. A arte da memória. Campinas: Editora da Unicamp, 2007.

Daniela Queiroz Campos: Visiting Professor from the Postgraduate Program in Visual Arts PPGAV at the Federal University of Bahia [UFBA] and postdoctoral fellow from the Institute of Language Studies [IEL] at the State University of Campinas [Unicamp] under the supervision of Professor Doctor Márcio Seligmann-Silva. Postdoctoral degree from the Centre d'Histoire et de Théorie des Arts [CEHTA] at the École des Hautes Études en Sciences Sociales [EHESS], Paris, under the supervision of Professor Georges Didi-Huberman. PhD in History at the Federal University of Santa Catarina [UFSC].

$\left(^{*}\right)$ This text was submitted in July 2015 and updated in 2017 for this publication. 